\title{
BLEEDING TIME, LYMPH TIME, AND CLOT RESISTANCE IN MEN ${ }^{1}$
}

\author{
By ALFRED L. COPLEY ${ }^{2}$ AND JOSEPH J. LALICH ${ }^{3}$ \\ (From the Hixon Laboratory for Medical Research, University of Kansas, School of Medicine, \\ Kansas City, Kansas)
}

(Received for publication September 15, 1941)

Hemostasis in a skin wound is measured by the bleeding time. This phenomenon was first observed by Duke in 1910 (1). Improvements in the bleeding time technique, as described by Duke $(1,2)$, have since been made. Roskam (3) washed the blood emerging from the wound with a fine jet of water at an even pressure and temperature in order to avoid disturbing the lips of the wound by blotting. Ivy, Shapiro, and Melnick (4) attempted to eliminate the variable of capillary tonus by applying the cuff of a sphygmomanometer around the arm with a pressure of 40 millimeters of mercury. Tocantins (5) devised an instrument with which he produced a uniform wound on the dorsal surface of the forearm. Dishoeck and Jongkees (6) produced surface skin wounds $4 \mathrm{~mm}$. in diameter on the lobe of the ear, thereby cutting the capillaries without injuring the larger vessels.

In order to control most of the known factors which influence the bleeding time, we felt it necessary to adopt the principle introduced by Döttl and Ripke (7) of bleeding into fluid. Variations in temperature have been shown by König (8) and Roskam (3) to influence the bleeding time in men, and by Döttl and Ripke (7) and the authors (9) to influence the bleeding time in mice. In carrying out these tests the temperature was constantly kept at $37.5^{\circ} \mathrm{C}$. Changes of venous pressure, movements of the hand and arm, and pressure on the wound margins in the process of blotting the blood have been eliminated. We were unable to control the size and the number of vessels cut. Nevertheless, we attempted to keep more constant the factors of skin elasticity and the number and size of vessels cut by inflicting deeper puncture wounds than are commonly employed. The objective was

\footnotetext{
1 Read in part before the Annual Meeting of the Federation of American Societies for Experimental Biology, Chicago, April 18, 1941.

2 Aided by a grant from the Dazian Foundation for Medical Research.

3 George A. Breon Fellow in Experimental Medicine.
}

to devise a clinical method in which the experimental conditions have been standardized with reference to the variables which can affect the bleeding time. The application of bleeding into fluid permitted observations of new phenomena which we present.

\section{METHODS}

A constant temperature bath, capable of maintaining 200 cc. of isotonic saline at $37.5^{\circ} \mathrm{C}$. was constructed. We have called this portable bath with a support for the hand the hemorrhagometer (Figure 1). The terminal phalanx of the third or fourth finger was cleaned with alcohol and immersed for 2 minutes into the bath to attain

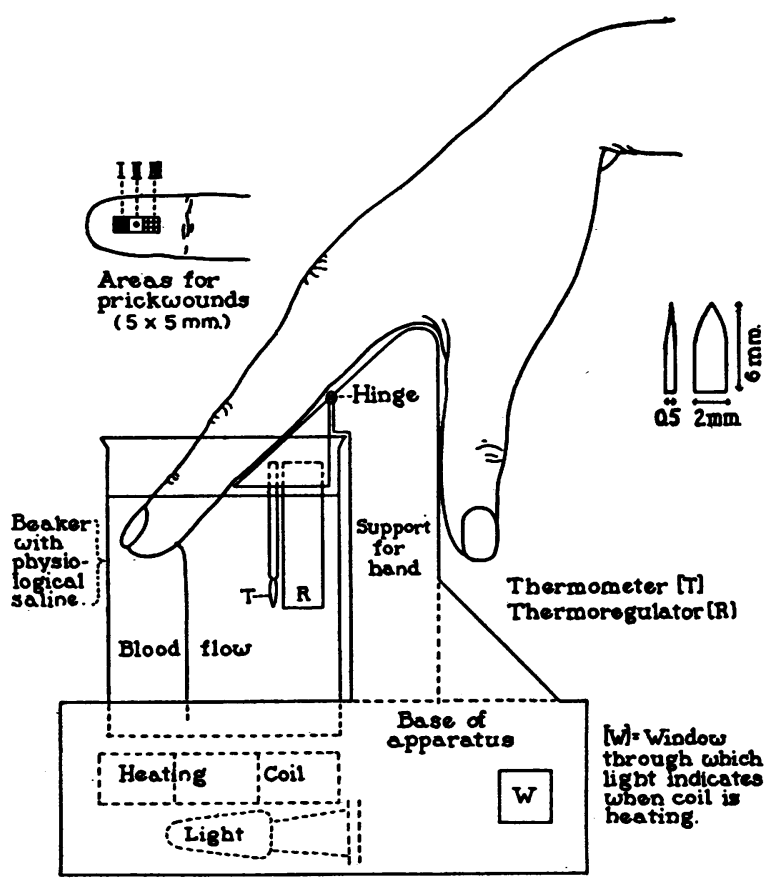

Note: Wiring not illustrated in diagram.

Fig. 1. Hemorrhagometer

the temperature of the saline bath. Usually prick wounds of the finger tip inflicted with a stylet measure from 2.5 to $3.5 \mathrm{~mm}$. in depth. We found that it was necessary to use a stylet with a strong spring and produce a wound depth of $6 \mathrm{~mm}$. to insure a free flow of blood. A mechanical stylet (Penn U.S.A. Chrome) with blade dimensions $0.5 \times 2 \times 6 \mathrm{~mm}$. was used (Figure 1). We had 
difficulty in maintaining the sharpness of the blade since commercial stylets are constructed of untempered steel. Area I of the finger, as shown in Figure 1, is to be preferred, since injury to the periosteum or bone is least likely. The heated phalanx was removed temporarily while the prick wound was inflicted. During the test the subject sat quietly in an armchair. The position of the hand was kept at a level of 10 to $15 \mathrm{~cm}$. below the base of the subject's heart to eliminate changes in venous pressure. The bleeding time was measured with a stop watch from the moment the wound was inflicted until the flow of blood stopped.

Two types of blood flow were differentiated following the production of the puncture wound: a non-pulsating, and a pulsating flow synchronous with the radial pulse. The pulsating flow may emerge with great force, perpendicular to the long axis of the finger; or it may flow directly down into the container. Not all perpendicular flows had pulsations synchronous with the heart beat. According to the amount of delivery of blood from the wound, the blood flow was further differentiated into various strengths: very strong (ss), strong (s), moderate $(m)$, feeble (f), and very feeble ( $f f)$. Usually the flow of blood diminished in strength or volume until hemostasis occurred. In the Tables the listed strength of flow indicates the maximum output of blood which occurred during the test. Occasionally we observed fluctuations, feeble flows being followed by strong ones.
The influence of various temperatures on the bleeding time was investigated, using saline solutions of the following temperatures: $12.5,25,37.5$, and $50, \pm 1^{\circ} \mathrm{C}$.

We observed, in addition to the red or blood flow, a whitish flow which may be observed alone or simultaneously with the red flow. The whitish flow, which we believe is a mixture of lymph, tissue fluid, and plasma was measured from the time the wound was inflicted until the flow stopped. We propose to name the duration of this whitish flow the "lymph time", in differentiation from the bleeding time. It may be noted that for the observation of the "lymph time", strong illumination and a clear physiological saline solution are required. At times this whitish flow may be interspersed with beadlike masses of blood and thus assumes a thread-like appearance.

A latent period was measured from the infliction of the prick wound until the blood flow started. Clot appearance at the site of the wound was observed during and following the bleeding time. The size and appearance of this external clot were studied.

The effect of capillary tonus (4) was investigated by applying a cuff-pressure of $40 \mathrm{~mm}$. $\mathrm{Hg}$ around the arm, after which the bleeding time and "lymph time" were determined. In another series of investigations, immediately after the "lymph flow" had stopped, a cuff-pressure of $100 \mathrm{~mm}$. $\mathrm{Hg}$ was applied for 3 minutes in order to observe whether a blood flow or "lymph flow" could be provoked.

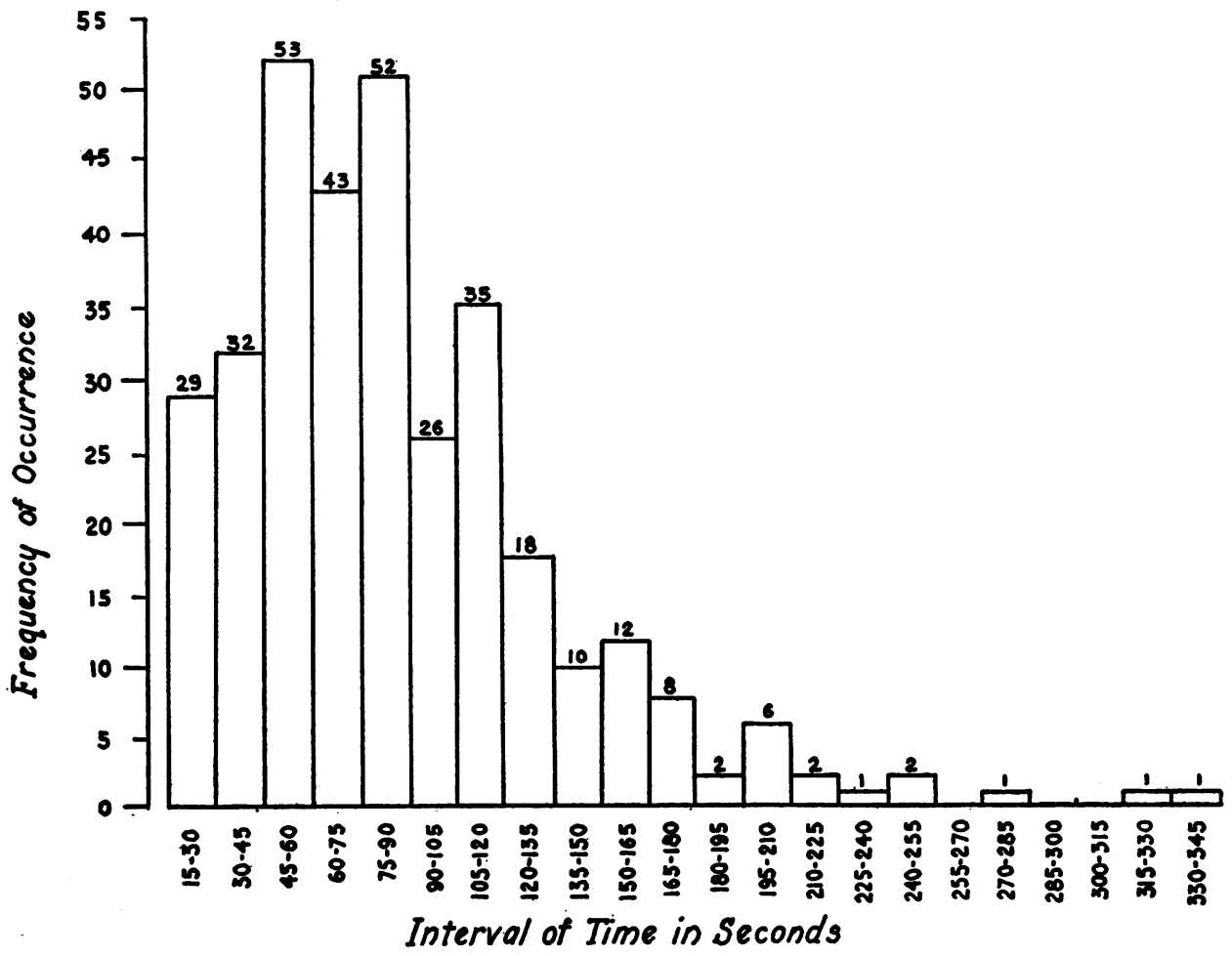

Fig. 2. Frequency Distribution of 334 Determinations of Bleeding Time in 174 Subjects 
RESULTS

\section{Bleeding time}

Figure 2 illustrates the frequency distribution of 334 single determinations of bleeding time in 174 subjects composed of medical students, the clinic staff and ambulatory clinic patients. The bleeding times ranged from 17 to 340 seconds. Eighty-seven per cent were from 30 to 180 seconds, and 95 per cent fell between 17 and 180 seconds. Five per cent of the values were found to be over 180 seconds. We consider bleeding time values between 3 and 6 minutes as slightly prolonged, and values over 6 minutes as pathological. Usually the latent period is from 0 to 4 seconds. Since most of the latent periods were less than 4 seconds, we included them in the bleeding time values.

TABLE I

Agreement of bleeding times taken within an hour

\begin{tabular}{c|c|c|c|c|c|c|c|c|c}
\hline \hline $\begin{array}{c}\text { Agreement } \\
\text { within } \\
8000 \text { ds }\end{array}$ & $1-15$ & $16-30$ & $31-45$ & $46-60$ & $61-75$ & $76-80$ & $91-105$ & $121-135$ & Total \\
\hline $\begin{array}{c}\text { Frequency } \\
\text { of } \\
\text { ocourrence }\end{array}$ & 62 & 42 & 19 & 11 & 7 & 2 & 1 & 1 & 145 \\
\hline $\begin{array}{c}\text { Ocourrence } \\
\text { in } \\
\text { per cent }\end{array}$ & 42.7 & 29.0 & 13.1 & 7.6 & 4.8 & 1.4 & 0.7 & 0.7 & 100 \\
\hline
\end{tabular}

Table I shows how the bleeding time values differ in two or more successive tests done within an hour. In those instances where three or four tests were done, an average was computed and the deviation from the average was expressed in seconds. It is shown that out of 145 comparisons, 104 of the values checked within \pm 30 seconds.

In Table II bleeding times are presented which were done on 10 individuals on successive occasions after intervals of days or months. On the same day variations from 67 to 197 seconds occurred in Case N. N. and from 54 to 204 seconds in Case A. L. C. These values show that infrequently wide divergencies may occur; however, tests over a longer interval of time agree closely. In such instances where one value was much less than others, we found it was usually due to the infliction of an inadequate puncture wound.

Table III shows the effect of temperature on the bleeding time. In order to lessen trauma only. two tests were done on one finger. It is evident
TABLE II

Repeated bleeding times in ten subjects

\begin{tabular}{|c|c|c|c|c|c|c|}
\hline \multirow{2}{*}{$\begin{array}{l}\text { Subject } \\
\text { T. P. R. }\end{array}$} & \multirow{2}{*}{$\begin{array}{c}\text { Date } \\
\text { 1940-1941 } \\
\begin{array}{l}\text { December } 6 \\
\text { December 10 }\end{array}\end{array}$} & \multirow{2}{*}{$\begin{array}{c}\begin{array}{c}\text { Num- } \\
\text { ber of } \\
\text { tests }\end{array} \\
2 \\
2\end{array}$} & \multicolumn{4}{|c|}{ Bleeding time in seconds } \\
\hline & & & $\begin{array}{l}f 60 \\
871\end{array}$ & $\begin{array}{r}f 62 \\
8369\end{array}$ & & \\
\hline N. N. & $\begin{array}{l}\text { November } 22 \\
\text { December } 3 \\
\text { December } 10\end{array}$ & $\begin{array}{l}4 \\
1 \\
2\end{array}$ & $\begin{array}{l}\text { s } 197 \\
\text { ff } 141 \\
\text { s } 135\end{array}$ & $\begin{array}{l}867 \\
f 177\end{array}$ & 8144 & s 159 \\
\hline E. C. & $\begin{array}{l}\text { November } 14 \\
\text { December } 10 \\
\text { May } 23 \\
\text { May } 29\end{array}$ & $\begin{array}{l}2 \\
2 \\
1 \\
1\end{array}$ & $\begin{array}{l}\text { f } 67 \\
\text { m } 114 \\
\text { m } 76 \\
\text { 8s } 39\end{array}$ & $\begin{array}{c}\text { f } 68 \\
\text { m } 109\end{array}$ & & \\
\hline B. L. & $\begin{array}{l}\text { November } 20 \\
\text { December } 6 \\
\text { June } 26\end{array}$ & $\begin{array}{l}2 \\
2 \\
1\end{array}$ & $\begin{array}{r}\text { f } 128 \\
\text { ff } 123 \\
\text { m } 200\end{array}$ & 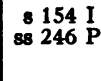 & & \\
\hline V.P. & $\begin{array}{l}\text { November } 4 \\
\text { December } 10 \\
\text { July } 5\end{array}$ & $\begin{array}{l}1 \\
2 \\
1\end{array}$ & $\begin{array}{r}\text { m } 35 \\
\text { f } 41 \\
855\end{array}$ & f 60 & & \\
\hline E. C. $\mathbf{K}$. & $\begin{array}{l}\text { December } 12 \\
\text { June } 26 \\
\text { August } 25\end{array}$ & $\begin{array}{l}1 \\
2 \\
1\end{array}$ & $\begin{array}{l}\text { m325 } \\
\text { m } 31 \\
8345\end{array}$ & 845 & & \\
\hline L. C. & $\begin{array}{l}\text { December } 6 \\
\text { August } 22\end{array}$ & $\begin{array}{l}2 \\
1\end{array}$ & $\begin{array}{l}\text { ff } 47 \\
\text { f } 44\end{array}$ & $\mathrm{~m} 66$ & & \\
\hline D. M. C. & $\begin{array}{l}\text { December } 6 \\
\text { June } 5 \\
\text { June } 26 \\
\text { August } 22\end{array}$ & $\begin{array}{l}3 \\
1 \\
2 \\
1\end{array}$ & $\begin{array}{ll}\text { m } & 215 \\
\text { ss } & 160 \\
88 & 330 \\
\text { ss } & 131\end{array}$ & $\begin{array}{l}\text { m } 230 \\
88170\end{array}$ & 88279 & \\
\hline J. J. L. & $\begin{array}{l}\text { September } 15 \\
\text { November } 14 \\
\text { November } 19 \\
\text { November } 20 \\
\text { December } 10 \\
\text { April } 8 \\
\text { August } 22\end{array}$ & $\begin{array}{l}2 \\
2 \\
1 \\
2 \\
2 \\
2 \\
1\end{array}$ & $\begin{aligned} & 48 \\
& \text { f } 27 \\
& \text { m } 73 \\
& \text { m } 110 \\
& 20 \\
& \text { f } 36 \\
& 864\end{aligned}$ & $\begin{array}{r}77 \\
\mathrm{f} \quad 69 \\
\text { ss } 90 \\
47 \\
\mathrm{f} \quad 32\end{array}$ & & \\
\hline A. L. C. & $\begin{array}{l}\text { September } 15 \\
\text { November } 14 \\
\text { November } 17 \\
\text { November } 19 \\
\text { December } 6 \\
\text { March } 26 \\
\text { August } 18 \\
\text { August } 22\end{array}$ & $\begin{array}{l}2 \\
2 \\
1 \\
1 \\
3 \\
2 \\
1 \\
2 \\
2\end{array}$ & 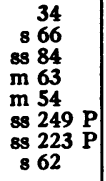 & $\begin{array}{r}35 \\
880 \\
\text { ff } 62 \\
\text { m 70 } \\
\text { ss } 53\end{array}$ & m 204 I & \\
\hline
\end{tabular}

ss $=$ very strong, $s=$ strong, $m=$ moderate, $f=$ feeble ff $=$ very feeble; $I=$ intermittent fluctuation in strength of flow; $\mathrm{P}=$ pulsating flow.

from this table that temperatures lower than $36.5^{\circ}$ C. prolong the bleeding time. Tests which were done at $50^{\circ} \mathrm{C}$. agreed closely with the values which

TABLE III

The effect of temperature upon the bleeding time

\begin{tabular}{l|l|l|l|l}
\hline Subject & $12.5^{\circ} \mathrm{C}$. & $25^{\circ} \mathrm{C}$. & $37.5^{\circ} \mathrm{C}$. & $50^{\circ} \mathrm{C}$. \\
\cline { 2 - 4 } & seconds & seconds & seconds & seconds \\
J. G. S. & 390 & 116 & 20 & $146 \mathrm{P}$ \\
L. C. K. & 275 & 151 & 21 & 15 \\
G. A. B. & 350 & 198 & 22 & 34 \\
R. S. & 163 & 72 & $23,68 \mathrm{P}$ & 55 \\
D. A. B. & $356 \mathrm{P}$ & 126 & 30 & 46 \\
D. L. & 185 & 154 & 40 & 42 \\
L. C. & 259 & $246 \mathrm{P}$ & 44 & 52 \\
M. H. L. & 126 & $127 \mathrm{P}$ & 45 & 31 \\
H. B. & $532 \mathrm{P}$ & 139 & 51 & 43 \\
A. L. C. & 521 & $216 \mathrm{P}$ & 58 & 52 \\
J. J. L. & 203 & 103 & 64 & 107 \\
M. S. & $398 \mathrm{P}$ & 250 & 82 & 33 \\
D. M. C. & $522 \mathrm{P}$ & $462 \mathrm{P}$ & 131 & $139 \mathrm{P}$ \\
& & &
\end{tabular}

$\mathbf{P}=$ pulsating flow. 
were obtained at $37.5^{\circ} \mathrm{C}$. We have found a relative increase in pulsating flows at lower temperatures. Pulsating flows augment the effect of lower temperatures by prolonging the bleeding time. Variations in the volume output of blood from the wound occurred more frequently at lower temperatures than at $37.5^{\circ} \mathrm{C}$. The latent periods were not significantly affected by changes in temperature.

Two to four repeated tests performed at different temperatures were obtained on 7 subjects. Values which were obtained at $37.5^{\circ} \mathrm{C}$. agreed closely, whereas this was less likely to be the case when bleeding times were done at $25^{\circ} \mathrm{C}$.

Of 345 bleeding times on 183 subjects without cuff pressure, eleven pulsating flows were seen which varied from 56 to 330 seconds, with an average of 183 seconds. With a cuff-pressure of $40 \mathrm{~mm}$. $\mathrm{Hg}$ in 53 persons, pulsating flows occurred 23 times, with variations from 46 to 330 seconds and with an average of 165 seconds. These results in normal individuals show that pul-

TABLE IV

The effect of $40 \mathrm{~mm} . \mathrm{Hg}$ of cuff-pressure on the bleeding time in twenty-five subjects

\begin{tabular}{|c|c|c|c|c|c|}
\hline \multirow{2}{*}{ Number } & \multicolumn{2}{|c|}{ Without cuff-pressure } & \multicolumn{2}{|c|}{ With cuff-pressure } & \multirow{2}{*}{$\begin{array}{c}\text { Difference } \\
\text { in } \\
\text { seconds }\end{array}$} \\
\hline & $\begin{array}{l}\text { Latent } \\
\text { period }\end{array}$ & $\begin{array}{c}\text { Bleeding } \\
\text { time }\end{array}$ & $\begin{array}{l}\text { Latent } \\
\text { period }\end{array}$ & $\begin{array}{c}\text { Bleeding } \\
\text { time }\end{array}$ & \\
\hline $\begin{array}{r}1 \\
2 \\
3 \\
4 \\
5 \\
6 \\
7 \\
8 \\
9 \\
10 \\
11 \\
12 \\
13 \\
14 \\
15 \\
16 \\
17 \\
18 \\
19 \\
20 \\
21 \\
22 \\
23 \\
24 \\
25\end{array}$ & $\begin{array}{l}\text { seconds } \\
3 \\
2 \\
1 \\
3 \\
3 \\
3 \\
3 \\
1 \\
3 \\
2 \\
0 \\
3 \\
3 \\
4 \\
4 \\
3 \\
4 \\
7 \\
2 \\
2 \\
2 \\
2.5 \\
4 \\
3 \\
3\end{array}$ & \begin{tabular}{cr}
\multicolumn{2}{c|}{ seconds } \\
m I & 270 \\
m & 99 \\
s & 340 \\
s & 60 \\
ss & 55 \\
m & 77 \\
m & 80 \\
ss P & 330 \\
s & 54 \\
m & 106 \\
ss & 56 \\
s & 52 \\
s & 82 \\
m & 37 \\
m & 27 \\
ss & 107 \\
s & 37 \\
m & 58 \\
ss P & 131 \\
s & 29 \\
s P & 56 \\
s & 45 \\
m & 76 \\
ss & 55 \\
ss & 550
\end{tabular} & $\begin{array}{c}\text { seconds } \\
2 \\
24 \\
2 \\
9.5 \\
2 \\
2 \\
2 \\
1 \\
4 \\
4 \\
3 \\
3 \\
3 \\
2 \\
3 \\
2 \\
1 \\
6 \\
2 \\
2 \\
1 \\
1 \\
1 \\
16 \\
3\end{array}$ & 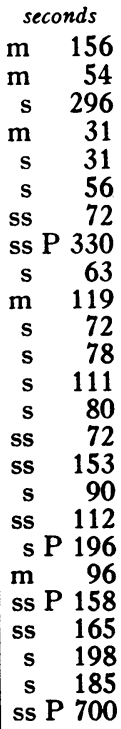 & $\begin{array}{l}-114 \\
-\quad 45 \\
-44 \\
-\quad 29 \\
-24 \\
-\quad 21 \\
-\quad 8 \\
+\quad 0 \\
+\quad 9 \\
+13 \\
+16 \\
+26 \\
+29 \\
+43 \\
+45 \\
+46 \\
+53 \\
+54 \\
+65 \\
+67 \\
+102 \\
+120 \\
+122 \\
+130 \\
+150\end{array}$ \\
\hline
\end{tabular}

ss $=$ very strong, $s=$ strong, $m=$ moderate $;=$ intermittent fluctuation in strength of flow; $\mathrm{P}=$ pulsating flow. sating flows are not appreciably longer than the usual or non-pulsating flows.

Table IV exhibits a comparison of the bleeding time done in the same subject with and without a cuff-pressure of $40 \mathrm{~mm}$. $\mathrm{Hg}$. The same finger was used in two successive tests. The results in 25 of 53 subjects who were studied for this comparison are shown. In 3 cases bleeding time was decreased from 114 to 44 seconds following cuffpressure. Values which checked within 30 seconds were observed in 10 cases, while in 11 cases there was an increase of 43 to 150 seconds. In the remaining 28 cases, not shown in this table, this relationship was essentially the same. The only prolonged bleeding time we observed (Case 25) occurred in a case of thrombopenia (platelets 45,000 , Lee and White coagulation time 9 minutes, Duke bleeding time 2 minutes). Latent periods were usually shortened by cuff-pressures of 40 $\mathrm{mm}$. Hg. However, in 7 of 53 instances latent periods were found between 6 and 24 seconds.

\section{New phenomena and their relation to bleeding time}

"Lymph time" tests were made on 73 persons. The values ranged from 0.5 to 50 minutes. Figure 3 shows the frequency distribution of "lymph time" values which ranged from 0.5 to 19 minutes in 68 persons. In 17 individuals the effect of 40 $\mathrm{mm}$. Hg cuff-pressure on the "lymph time" was studied. This cuff-pressure was found to increase the "lymph time" slightly in the majority of instances.

The phenomenon of clot appearance over the mouth of the wound was observed. Bleeding time, "lymph time", and clot appearance were compared in 53 subjects. Twenty-five of those are shown in Table V. No apparent correlation exists between the bleeding time and the "lymph time". Invariably the "lymph time" is of longer duration than the bleeding time. In 6 subjects no external clot was seen after the bleeding time and "lymph time" measurements were completed. In 8 other cases external clots which had formed towards the end of the bleeding time test did not change in size during the period of "lymph flow". In 8 subjects in whom no clot was visible at the termination of the bleeding time, clot appearance was observed towards the end of the "lymph flow". 


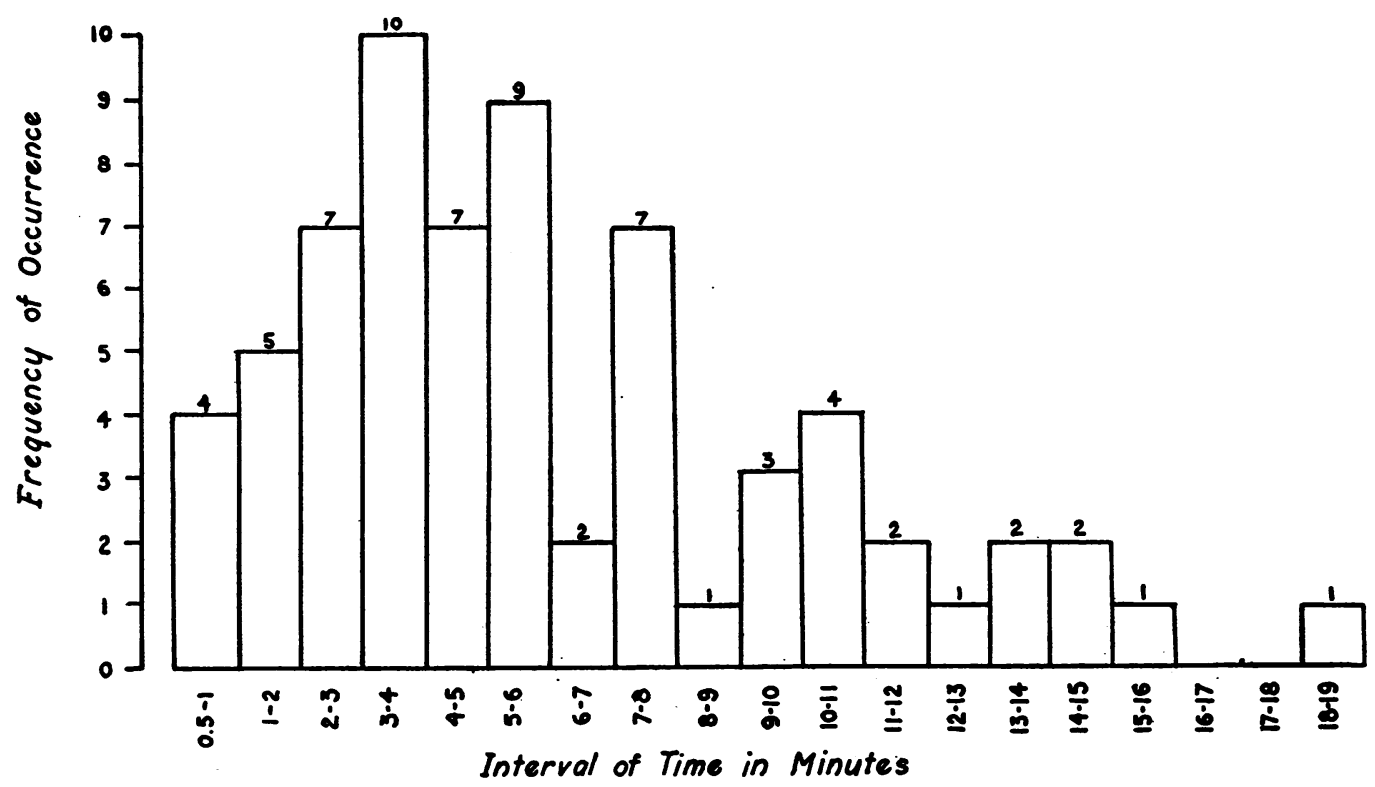

Fig. 3. Frequency Distribution of 68 Determinations of Lymph Time in 68 Subjects

Five subjects not shown in this figure had values which varied from 25 to 50 minutes.

In 3 cases the external clot which was observed at the end of bleeding time enlarged during the flow of "lymph". Table V suggests that clot appearance does not occur with shorter bleeding and shorter "lymph flows".

\section{Experiments with $100 \mathrm{~mm}$. of mercury cuff- pressure}

An attempt was made to renew the flow of blood or "lymph" following intervals of 0.5 to 50 minutes after bleeding had stopped. The effects of a cuff-pressure of $100 \mathrm{~mm}$. $\mathrm{Hg}$ for 3 minutes were studied on 55 subjects in order to determine whether the clot which had formed inside of the wound would be able to resist such an increase in venous pressure.

In 3 cases the clot was unable to resist this pressure, and a flow of blood started again. These red flows began from 49 to 234 seconds after the blood flow had stopped and lasted from 90 to 240 seconds. In each instance, these blood flows stopped while the pressure was being maintained. In this group of persons it was not possible to make a wound resume bleeding with this pressure 4 minutes after blood flow had stopped.

"Lymph flows" were renewed in 45 instances. In 39 cases the flow of "lymph" continued over the 3-minute period, and in 6 instances "lymph flow" stopped before the 3 minutes were over. In 7 other cases no "lymph flow" was initiated by the cuff-pressure.

TABLE $V$

Comparison of bleeding time, lymph time and clot appearance

\begin{tabular}{|c|c|c|c|c|}
\hline Case & $\begin{array}{l}\text { Bleeding } \\
\text { time }\end{array}$ & $\begin{array}{l}\text { Clot after } \\
\text { flow of } \\
\text { blood }\end{array}$ & $\begin{array}{l}\text { Lymph } \\
\text { time }\end{array}$ & $\begin{array}{l}\text { Clot after } \\
\text { flow of } \\
\text { lymph }\end{array}$ \\
\hline $\begin{array}{r}1 \\
2 \\
3 \\
4 \\
5 \\
6 \\
7 \\
8 \\
9 \\
10 \\
11 \\
12 \\
13 \\
14 \\
15 \\
16 \\
17 \\
18 \\
19 \\
20 \\
21 \\
22 \\
23 \\
24 \\
25\end{array}$ & \begin{aligned} & \multicolumn{2}{c}{ seconds } \\
& ff 18 \\
& f 25 \\
& m 25 \\
& m 26 \\
& s 42 \\
& m 45 \\
& m 47 \\
& m 52 \\
& s 54 \\
& ss 56 \\
& s 62 \\
& f 79 \\
& s 79 \\
& f 81 \\
& s 88 \\
& ss 108 \\
& ss 115 \\
& ss 130 \\
& s 157 \\
& s 158 \\
& m 160 P \\
& m 200 \\
& m 243 \\
& m 285 \\
& ss 330\end{aligned} & $\begin{array}{l}\text { None } \\
\text { None } \\
\text { None } \\
\text { None } \\
\text { None } \\
\text { None } \\
\text { None } \\
\text { None } \\
\text { None } \\
\text { Present } \\
\text { None } \\
\text { Present } \\
\text { None } \\
\text { Present } \\
\text { None } \\
\text { Present } \\
\text { None } \\
\text { Present } \\
\text { Present } \\
\text { Present } \\
\text { None } \\
\text { None } \\
\text { Present } \\
\text { Present } \\
\text { Present }\end{array}$ & $\begin{array}{c}\text { seconds } \\
32 \\
465 \\
700 \\
118 \\
635 \\
184 \\
330 \\
439 \\
3000 \\
1620 \\
274 \\
184 \\
495 \\
290 \\
720 \\
190 \\
360 \\
910 \\
212 \\
615 \\
270 \\
320 \\
475 \\
870 \\
480\end{array}$ & $\begin{array}{l}\text { None } \\
\text { Present } \\
\text { Present } \\
\text { None } \\
\text { Present } \\
\text { None } \\
\text { None } \\
\text { None } \\
\text { Present } \\
\text { Enlarged } \\
\text { Present } \\
\text { Not enlarged } \\
\text { Present } \\
\text { Enlarged } \\
\text { Present } \\
\text { Not enlarged } \\
\text { Present } \\
\text { Not enlarged } \\
\text { Not enlarged } \\
\text { Not enlarged } \\
\text { None } \\
\text { Enlarged } \\
\text { Not enlarged } \\
\text { Not enlarged } \\
\text { Not enlarged }\end{array}$ \\
\hline
\end{tabular}

ss $=$ very strong, $s=$ strong, $m=$ moderate, $f=$ feeble, ff $=$ very feeble; $\mathbf{P}=$ pulsating flow. 
The effect of cuff-pressure on the clot appearance was also studied. No change was seen in the external clots which had appeared in 15 instances at the end of bleeding or during the "lymph flow". In 15 other cases, the external clot was enlarged following application of cuffpressure. In 7 persons no clot appeared after pressure.

During the flow of "lymph" we occasionally observed the whitish flow interspersed with beadlike red masses. These masses may be due either to the escape of blood from opened vessels at intervals or to disintegration of the clot. This flow was produced following application of cuffpressure in 12 of 55 instances, and it lasted from 15 to 120 seconds. In eleven cases this flow occurred from 2 to 9 minutes following the cessation of the blood flow.

\section{DISCUSSION}

\section{The normal bleeding time}

The normal Duke bleeding time is between 30 and 180 seconds according to Ivy, Shapiro and Melnick (4) and between 60 to 180 seconds according to Tocantins (5). Ninety-five per cent of our values were between 17 and 180 seconds. One wonders if bleeding times between 3 and 6 minutes, which we designate as slightly prolonged, are pathologic. We cannot answer this question at the present time. Values over 6 minutes, which we regard as pathologic, were found in but one case of thrombopenia. As a rule, the majority of the bleeding times in one individual agree within \pm 30 seconds. In the case of E. C. K. (Table II), where $6 \frac{1}{2}$ months elapsed between tests, it is possible that the hemostatic function of the skin may have undergone a change during this time. Tests performed at $37.5^{\circ} \mathrm{C}$. have shorter bleeding times than at $25^{\circ} \mathrm{C}$. and agree more closely when repeated. These findings are, on the whole, similar to data obtained by Dale and Laidlaw (10) in studies on the influence of temperature upon the blood coagulation time. In contrast to the results of Roskam (3), we found that the bleeding time is practically the same at $37.5^{\circ} \mathrm{C}$. as at $50^{\circ} \mathrm{C}$. The increased incidence of pulsating flow following application of cuff-pressure may be due to the transmission of the arteriolar pulsation into the capillaries following venous obstruction.

Our method can be used to study hemostatic substances in vivo, or locally by adding them to the isotonic saline bath. Furthermore, studies on the fragility of the erythrocytes can be undertaken directly by changing the tonicity of the saline bath.

It is known that following the production of a puncture wound the capillaries contract initially and that dilatation occurs (11). The duration of this initial contraction may be obtained by measuring the latent period. Our findings indicate that the initial capillary contraction may not be eliminated by $40 \mathrm{~mm}$. $\mathrm{Hg}$ cuff-pressure. Probably the pain stimulus produced by the infliction of the puncture wound is responsible for these long latent periods.

\section{The lymph time}

In the production of the puncture wound not only are the blood vessels injured, but the tissue spaces, cells, and the lymph vessels are also opened. Since we were unable to differentiate tissue fluid from lymph, we assume that these fluids are mixed following injury. It may be noted that the rose coloration of the whitish flow may be due to the admixture of red blood cells with the tissue fluid. We do not believe that this whitish flow is serum from the clot which has formed in the wound for the following reasons: First, the whitish flow can be observed simultaneously with the red flow; second, we have frequently found that an inadequate puncture wound will produce a whitish flow without any blood. The reason why the "lymph" continues to flow after the bleeding stops is probably due to the hypocoagulability of the lymph. It is well established that lymph coagulates (12).

The majority of lymph times are below 16 minutes. The significance of the lymph time cannot be evaluated at present. We suggest that it may be a measure of wound seepage which might affect wound healing. The slightly increased "lymph time" on application of $40 \mathrm{~mm}$. $\mathrm{Hg}$ cuff-pressure may be due to the increased lymph flow resulting from the increased venous pressure. 


\section{The blood clot}

Agglutination of platelets and blood coagulation are two separable processes in mammals (13). We believe that both the agglutination of platelets and the conversion of fibrinogen to fibrin are responsible for the firmness of the clot and its ability to plug the wound. Usually the clot which forms inside of the wound is sufficient to stop the blood flow, although it may not prevent the seepage of "lymph". In the majority of cases, the clot which has formed in the wound extends beyond the wound margins and thus becomes what we have called "the external clot" or "clot appearance." During the flow of "lymph", the external clot may enlarge. A correlation between clot appearance and duration of bleeding time or "lymph time" is suggested in Table V. However, only future investigation can clarify these points.

Tocantins (5) described a method in which he applied negative pressures with a suction cup. $\mathrm{He}$ found that a cut in the skin can be made to resume bleeding and suggested that this method might be of use to indicate a bleeding tendency during or after operation. In order to avoid local disturbance of the clot and the wound, we tested the clot resistance against a venous cuff-pressure of 100 $\mathrm{mm}$. $\mathrm{Hg}$ for 3 minutes.

Increasing the cuff-pressure to $100 \mathrm{~mm}$. $\mathrm{Hg}$ often increased the size of the external clot. This may be due to the increased pressure in the capillary bed and engorgement of the tissue spaces. It is very difficult to dislodge the clot and provoke the flow of blood again once bleeding has stopped in normal individuals. Complete dislodgment of the clot, which was indicated by a renewal of the red flow, occurred in but 3 cases. In no instance was it possible to dislodge the clot 4 minutes, or longer, after the blood flow had stopped. In contrast to this, clot resistance studies in 2 cases of hemophilia differed markedly. In both hemophiliacs whose bleeding times were normal it was possible to renew the flow of blood by applying $100 \mathrm{~mm}$. Hg pressure 75 minutes after bleeding had stopped. The bleeding stopped within 30 seconds, however, when the cuff-pressure was reduced to $40 \mathrm{~mm}$. of mercury. Clot resistance expresses both the solidity of the clot and its ability to adhere to the skin wound. Clot resistance is therefore a measure for hemostasis.
Magnus (14) contended that the all-important factor in the control of capillary bleeding is the ability of the vessel wall to contract. Macfarlane (15), however, while emphasizing that capillary contraction plays the primary rôle in the cessation of bleeding, admits that the solidity of the clot is an important factor. It cannot be denied that the capillaries are involved in the cessation of bleeding from a wound; however, we feel that definite proof is lacking that capillary contraction plays the primary rôle in hemostasis. In this connection it may be of interest to report a case of postoperative shock during which bleeding times were 17 and 30 seconds. We have shown in a previous communication (9) that excessive doses of heparin can produce bleeding tendencies in most mice, and bleeding times longer than 30 minutes in some. Several mice which had a normal bleeding time could still bleed to death from their prick wound if they dislodged the clot which covered the wound. These findings and the results in the two hemophiliacs support the hypothesis that the firmness with which the clot is attached to the wound plays a vital rôle in hemostasis.

\section{SUM MARY}

A new method for the determination of bleeding time is described in which the principle of bleeding into fluid is employed. Various factors known to influence the bleeding time were controlled. Blood flows were differentiated with respect both to the volume output of blood from the wound and pulsation of the flow. The range of normal bleeding time for this method was established. The effects of temperature and capillary tonus on the bleeding time were studied.

The phenomena of "lymph time", latent period, a beaded flow of blood, clot appearance, and clot resistance are described. In normal individuals, the clot, when formed, could not be dislodged by applying $100 \mathrm{~mm}$. of mercury cuff-pressure 4 minutes after bleeding had stopped. In 2 hemophiliacs, however, it was possible to dislodge the clot and renew the blood flow 75 minutes after the cessation of bleeding. The mechanism of hemostasis is discussed. 


\section{BIBLIOGRAPHY}

1. Duke, W. W., The relation of blood platelets to hemorrhagic disease. Description of a method for determining the bleeding time and coagulation time and report of three cases of hemorrhagic disease relieved by transfusion. J. A. M. A., 1910, $55,1185$.

2. Duke, W. W., The pathogenesis of purpura hemorrhagica with especial reference to the part played by blood-platelets. Arch. Int. Med., 1912, 10, 445.

3. Roskam, J., Température et temps de saignement. Compt. rend. Soc. de biol., 1933, 112, 1245.

4. Ivy, A. C., Shapiro, P. F., and Melnick, P., The bleeding tendency in jaundice. Surg. Gynec. and Obst., 1935, 60, 781.

5. Tocantins, L. M., The bleeding time. Am J. Clin. Path., 1936, 6, 160.

6. Dishoeck, H. A. E. v., and Jongkees, L. B. W., Eine neue Methode zur Bestimmung der Blutungszeit. Klin. Wchnschr., 1940, 19, 1216.

7. Döttl, K., and Ripke, O., in Medicine In Its Chemical
Aspects. Vol. III. Bayer, Leverkusen, Germany, 1938, p. 252.

8. König, L., Versuche über Blutstillung. Klin. Wchnschr., 1922, 1, 2376.

9. Copley, A. L., and Lalich, J. J., The experimental production of a hemophilia-like condition in heparinized mice. Am. J. Physiol., 1942, 135, 547.

10. Dale, H. H., and Laidlaw, P. P., A simple coagulometer. J. Path. and Bact., 1911-1912, 16, 351.

11. Magnus, G., Der Beginn der Entzündung im Bilde direkter Capillarbeobachtung. Arch. f. klin. Chir., 1922, 120, 96.

12. Drinker, C. K., and Field, M. E., Lymphatics, Lymph and Tissue Fluid. Williams and Wilkins. Baltimore, 1933.

13. Best, C. H., Heparin and thrombosis. The Harvey Lectures, 1940-41, Series 36, p. 66.

14. Magnus, G., Experimentelle Untersuchungen über den segmentären Gefässkrampf und den Blutungsstillstand. Arch. f. klin. Chir., 1924, 130, 237.

15. Macfarlane, G. R., Critical review: The mechanism of hemostasis. Quart. J. Med. (New Series), 1941, 10, 1. 